WellBeing International

WBI Studies Repository

2020

\title{
Reopening the Trade after SARS: China's Wildlife Industry and the Fateful Policy Reversal
}

Peter Li

Follow this and additional works at: https://www.wellbeingintlstudiesrepository.org/es_ee

\section{Recommended Citation}

Li, P. (2020). Reopening the trade after SARS: China's wildlife industry and the fateful policy reversal. Environmental Policy \& Law 50:1-17. DOI 10.3233/EPL-201008

This material is brought to you for free and open access by WellBeing International. It has been accepted for inclusion by an authorized administrator of the WBI Studies Repository. For more information, please contact wbisr-info@wellbeingintl.org.

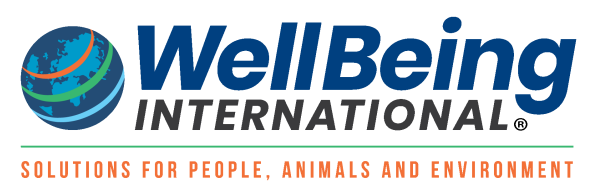




\title{
Reopening the Trade after SARS: China's Wildlife Industry and the Fateful Policy Reversal
}

\author{
Peter $\mathrm{Li}^{*}$ \\ Associate Professor of East Asian Politics, Animal Policy and Law, University of Houston-Downtown, Houston, \\ Texas, USA
}

\begin{abstract}
China's policy-making remains a top-down process. Yet, non-State actors, particularly businesses that have aligned their commercial interest with the national interest and political objectives of the Party-State, are uniquely positioned to impact policy-making. This article uses China's reopening of the wildlife trade following the end of SARS in 2003 to shed light on the interplay of the Party's policy guidelines, the policy-making authority of the administrative agencies, and the influence of the country's wildlife business interest. This article argues that the reversal of the wildlife trade ban was predestined since expanding wildlife business also contributed to the government's development objectives and served the bureaucratic interest of the administrative authorities. In 2003, the wildlife businesses had unique lobbying power. It was a production of scale that purportedly served the country's conservation, public health and poverty-reduction purposes. The failure of the Chinese scientists to reach a consensus on the risk of pandemic outbreaks from wildlife operations helped the Chinese authorities to end the wildlife trade, a fateful decision. The outbreak of COVID-19 has led to an enhanced understanding of the connections between wildlife exploitation and pandemic outbreaks. China has come to a crossroads to evaluate the cost-effectiveness of its wildlife industry.
\end{abstract}

Keywords: China, wildlife policy, policy-making, Party-State, non-State actors

The COVID-19 pandemic is arguably the most devastating global public health crisis since the 1918 flu pandemic. Despite alternative interpretations, existing scientific evidence connected the current pandemic to a wildlife market in Wuhan, China. ${ }^{1}$ On 1 January 2020, the Chinese government shut down the market; on 23 January, it imposed a nationwide wildlife trade and consumption ban (hereafter trade ban), and elevated the ban as a national legislative decision on 24 February. These decisions are reminiscent of the short-lived trade ban taken by the Chinese government in response to

*Corresponding author. E-mail: lip@uhd.edu.
SARS (severe acute respiratory syndrome) that had broken out in November 2002. The current trade ban has failed to contain the pandemic inside the Chinese borders. It is still ravaging much of the world at the time of this article's writing.

The question over whether China's current trade ban will be lifted worries many who have criticised China for its failure to maintain the trade ban after SARS. China's reopening the trade 17 years ago was, in retrospect, a fateful decision. There is no better time to take a closer look at the events and forces that led to the resumption of the wildlife trade. How could China have reversed the trade ban when Chinese scientists had traced the SARS pandemic to wild animals sold and processed for food on the wildlife markets? What 
was the role of the country's wildlife businesses in the policy reversal?

\section{Wildlife Trade and Policy Change in China}

This article does not attempt to cover the entire commercial empire of wildlife trade. It focuses on the part of the operation - wildlife trade and farming operations for the exotic food market - that is linked to SARS and COVID-19. Its purpose is to examine how the industry succeeded in helping shape the fateful policy reversal in 2003. For this purpose, it begins with a brief look at China's wildlife trade and policy-making, which will establish a roadmap for the subsequent analysis.

\subsection{Wildlife Trade}

Wildlife trade covers a wide range of commercial activities. The part of the trade that is commonly known involves transnational and trans-continental shipment of live animals, parts and processed products across national borders. In China, the trade also has a robust and large domestic component. China's domestic wildlife trade has been largely sustained by its wildlife industry that consists of a gigantic commercial breeding operation and other derived businesses such as animal feed production, veterinary supply production, trans-provincial shipping, wildlife wholesale and retail sales, exotic food catering, Traditional Chinese Medicine (TCM) drug production, fur processing and garment production, and captive wildlife display and entertainment. Commercial breeding of wildlife in China has five components. Fur animal farming is the biggest operation that produced a revenue in 2016 of 389 billion yuan (US \$59 billion). The second biggest is breeding for the exotic food markets and for wild animal meat consumption. This sector farms hundreds of wild animal species and produced a revenue of 125 billion (US $\$ 19$ billion) in the same year. The other three are operations that supply the TCM producers, zoo and pet markets, and research facilities. ${ }^{2}$ Wildlife trade and consumption (hereafter wildlife trade) in this article refers to the farming operation that supplies the exotic food markets, live transport and wild animal meat consumption. This is also the part of the trade that was shut down in 2003 because of SARS and has been again shut down in 2020.

\subsection{Policy Change in China}

Despite economic liberalisation, China has remained a Leninist Party-State. Policy-making and changing an existing policy are a largely closed process dominated by the Party and the State administrative agencies. The National People's Congress, China's national legislature, has been increasingly active. Yet, legislative agendas are controlled by the Chinese Communist Party (CCP) Central Committee. ${ }^{3}$ Three actors stand out in the process. First, the Party Central Committee produces policy guidelines, political objectives, and the general direction of the country's social and economic development to guide law-making and policy-making. Second, the functional agencies of the government are key actors assisting the legislatures in the making of laws and policies. And third, non-State actors such as registered non-governmental organisations, professional associations, private businesses and others have controlled participation in the policy-making process.

\subsubsection{The Party's Policy Guidelines}

China's policy-making is a top-down process. The Politburo of the CCP Central Committee decides on major policy guidelines that include the Party's position on major issues, political objectives to be achieved in a specific period, and the general orientation of the country's social, political and economic development. ${ }^{4}$ Once the Party's new policy guidelines are established, corresponding adjustments or changes may be made to existing laws, rules, regulations and policies. New policies were adopted, new production models introduced, and a new system of rural governance was formed following the adoption in 1958 by the Party Central Committee of new policy guidelines to accelerate and complete the socialist transformation of the economy. ${ }^{5}$ Similarly, the shifting in 1978 of the Party's main task to economic modernisation led to the policy of reform and opening up to the outside world. In the ensuing years, collective farms were disbanded; private production was decriminalised; decision-making was decentralised; and the rural market was reopened. Economic policies of the pre-reform era were subsequently revised or abolished. ${ }^{6}$ In general, Chinese laws and policies do not divert from or contradict the Party's guidelines. 


\subsubsection{The Administrative Agencies}

In the last four decades, institutional actors, i.e., administrative agencies, have become more prominent in policy-making. This policy-making role of the bureaucratic agencies has contributed to the increase of their power, autonomy and assertiveness. ${ }^{7}$ In 2013, China's Party leadership initiated the much anticipated legislative move to amend, through the National People's Congress, the country's Wildlife Protection Law (WPL). ${ }^{8}$ Involved extensively in the WPL revision was the State Forestry Bureau (SFB), the national government agency for managing wildlife. Each one of the provisions of the revised law bore the imprint of the SFB. ${ }^{9}$ Similarly, the country's other administrative agencies were deeply involved in the making of regulations in their professional areas. ${ }^{10}$ By 2006, 75-85 percent of the legislative bills had been drafted by the administrative agencies. These agencies were also responsible for making administrative regulations and rules. ${ }^{11}$

China's Party-State is not a monolithic whole. With the increase in power and assertiveness came the expansion of their bureaucratic interests that are not always in line with the national and public interests. To protect the parochial interests derived from their authority in project approval, fee collection and penalty enforcement, institutional actors are known to withhold, sift or ignore information and even science, from their superiors in policy-making. The result is the making of a policy that protects bureaucratic interests at the expense of the national interest. ${ }^{12}$ Some agencies have done so in the name of protecting national interests and for allegedly strengthening their regulatory capacity. ${ }^{13}$ Bureaucratic interests taking precedence over the public interest is no secret. ${ }^{14}$

Bureaucratic agencies with major regulatory responsibilities can become defenders of the businesses under their supervision. ${ }^{15}$ This can be a result of a distorted regulatory authority. To these agencies, economic gains can take precedence over the general societal interest of public health, safety and security. When their defence of business interests in service of their own bureaucratic interests reaches a certain degree, political risks triggered by lack of government regulation of an industry can threaten political stability. "If the functional departments of the people's government only represent the interests of a group or individuals, not the interest of the people, they can damage the interests of the people, the authority of the government, and the image of the Communist Party". 16

\subsection{Private Businesses}

Although the Party-State continues to monopolise policy-making power, the process is slowly opening up to the public. ${ }^{17}$ The Chinese authorities have even taken actions to initiate mechanisms for public participation and civic engagement with decision-making. Private businesses are particularly sensitive to and have a stake in policy change and are increasingly active. ${ }^{18}$ The authorities have taken proactive moves to co-opt the country's private entrepreneurs in an effort to channel their activism constructively into the policy-making process. The aim was to render their participation non-threatening to the status quo. ${ }^{19}$

The CCP's decision in 2001 to open Party membership to private business owners was such an act, intended to turn their otherwise autonomous lobbying activities into controlled participation in policy-making. ${ }^{20}$ The authorisation for the building of professional or industrial associations that are placed under State supervision was another institutional channel for private enterprises to have their voices heard. ${ }^{21}$ The Chinese government has also opened online consultation opportunities and internal meetings for policy-making purposes to citizens and businesses.

Business lobbying had been an "under-appreciated dynamic" until the early 2000 s. $^{22}$ Studies found that business lobbying was rising and making an impact. ${ }^{23}$ Businesses of scale were particularly influential. An industry that contributes more to the local and national economy; that employs more labourers particularly from the rural areas; and that helps fight poverty, weighs more in the government's calculation during policy-making. To be abreast of changes in government policies and be ready to fight for their interests, businesses are known to maintain frequent contacts with policy-making agencies and legislatures at the local and national levels; and sponsor and participate in policy-related meetings and seminars. They support policy research by academics and are quick to use scholarly publications for their purposes; access the media; engage in philanthropy; and hold catered events to develop and maintain relations. The supposedly 
omnipresent guanxi (personal relationships with government officials) has diminished in importance. Local protectionism and bureaucratic interests have so developed that local authorities and administrative agencies can become willing spokespersons for the business community. This is particularly so when business interests serve the political objective of the local governments and especially if the existence of a particular industry has been the reason underlying an administrative agency's expanded function or increased budget. ${ }^{24}$

In the following sections, we ask how the reversal of the trade ban in 2003 was as much a result of the country's general policy orientation as the influence of the wildlife industry. What were the policy guidelines and political objectives of the Party-State at the time of the SARS outbreak? What made China's wildlife industry influential as a business actor? What incentivised the country's functional agency to support the lifting of the trade ban?

\section{SARS, the Trade Ban and the Policy Reversal}

Breaking out in China's Guangdong province in November 2002, SARS was the first pandemic of the $21^{\text {st }}$ century. It took six months for Chinese scientists to ascertain the source of the virus. ${ }^{25}$ On 23 May 2003, researchers from Hong Kong and Shenzhen announced that the coronavirus that had triggered SARS was found in three wild animal species (Himalayan palm civets, Raccoon dogs and Ferret-badgers) sold for food in Guangdong's exotic food markets. The identified virus was 99 percent identical to the one that had sickened the first group of patients. This finding was later published in a peer-reviewed journal. ${ }^{26}$ On 24 May, China's Ministry of Agriculture announced that its researchers had identified other wild animals such as bats, monkeys and snakes from 1,700 samples of 59 species as carriers of coronavirus. ${ }^{27} \mathrm{~A}$ trade and consumption ban was soon imposed by the Guangdong authorities on 26 May. ${ }^{28}$ Earlier, a national trade ban had been imposed on 29 April by the SFB and the National Industrial and Commercial Administration (NICA) based on the fact that the first group of SARS patients had connections to wildlife trade and catering businesses. ${ }^{29}$

The nation-wide trade and consumption ban covered the entire industry. It revoked farming, hunting, import and export, and all related business permits; it ended animal performances, photo ops and other intimate human-animal contact programmes at zoos; it halted hunting, breeding, trading and wet marketing and slaughtering of wild animals; it locked down all wildlife farms; and also brought all wildlife shipping activities to a halt. Law enforcement actions were conducted nationwide. Between 28 May and 1 June, Guangdong conducted a "Green Sword" operation, confiscating more than 30,000 wild animals. At the same time, NICA issued seven directives for starting nationwide law enforcement actions by provincial market regulators. In the following weeks, a total of 1.98 million market inspection trips were made, uncovering 199,600 illegal sales cases. ${ }^{30}$ The SFB also implemented a "Spring Thunder" operation to fight wildlife crime. The campaign uncovered 9,000 cases and confiscated more than 900,000 wild animals. ${ }^{31}$ The wildlife industry faced its biggest crisis since the start of operations in the 1980s. ${ }^{32}$ The trade ban sent hundreds of thousands of wildlife breeders, traders, transporters, wet market operators and exotic food restaurant workers into a sudden financial crisis.

\section{The Reversal}

In the first six months of 2003, China scrambled to control SARS. When the pandemic broke out, wildlife had been designated as a natural resource to be used for economic development. The Chinese public and scientific community had no idea that this source of income could trigger a global public health disaster. Even in 2003, when SARS was ravaging the world, China did not see commercial use of wildlife as a public health threat.

But China knew that its wildlife industry was not controversy-free. For years, there had been criticism of the farming conditions and animal welfare. In 1993, Jill Robinson, who later founded Animals Asia Foundation, was the first to expose China's bear-farming cruelty. ${ }^{33}$ In 1998 , the International Fund for Animal Welfare (IFAW) surveyed urban Chinese attitudes towards wildlife use in traditional medicine, wildlife farming conditions, protection of endangered species, and animal protection in general. The survey confirmed that a majority of the respondents in the surveyed cities disapproved of the use of wild animals in TCM and that they found cruelty unacceptable. In this survey, the public health hazards of wildlife farming were not included 
in the questionnaire. ${ }^{34}$ Similarly, Li Xiaoxi, the first Chinese activist who appealed in 1998 to the Minister of Agriculture for an end to bear farming, also focused on the welfare problem of the farming practices. The public health risk of the wildlife industry had not yet caught the attention of the general public, the scientific community and the Chinese authorities. At the turn of the century, the national discourse in China centred on economic development, poverty reduction, and job creation.

The trade ban began to crumble even before SARS was over. On 10 June, the SFB issued the "Notice on the Need to Implement a Strict Ban on Illegal Hunting and Trade of Terrestrial Wild Animals in line with the New Situation". 35 This was obviously a corrective policy statement to water down the trade ban on "terrestrial wild animals" only, thus excluding aquatic and amphibian species such as frogs and turtles. Throughout this policy document, the words "terrestrial wild animals" were apologetically repeated 53 times, apparently to reassure the country's turtle and frog farmers that their farming operation would be re-opened. ${ }^{36}$ On 19 June, the foundation of the trade ban was shaken. A research team from the China University of Agriculture (CUA) announced in Beijing that they found no SARS coronavirus among the wild animals under study, including civet cats collected from the markets. ${ }^{37}$ This study, which had not gone through a peer-review process and was not published, overturned the earlier findings by the scientists from Hong Kong University (HKU), Shenzhen Center for Disease Control and Prevention (CDC) and the Ministry of Agriculture. The CUA findings came at the right time for the country's wildlife businesses and for the SFB.

The trade ban's impending demise became more apparent towards the end of June. When the Guangdong provincial government banned wildlife trade on 26 May, it went further and proposed a draft "regulation on patriotic public health work" to the $10^{\text {th }}$ provincial legislature. Article 7 of the proposed regulation was on a complete ban of wildlife consumption. ${ }^{38}$ However, only two months later at the 2nd plenary session of Guangdong's 10th People's Congress, Article 7 was changed to "no consumption of wild animals that are protected by laws, that are prone to spreading diseases, and that are not quarantined". 39 The amended article revealed that a complete wildlife consumption ban had been resisted by a coalition of business and bureaucratic interests.
On 5 August 2003, through its "Policy Document 121 ", the SFB officially lifted the trade and consumption ban. It announced that 54 wild animal species, including civet cats, alligators, Sika deer and others, were allowed to be farmed, traded and consumed. ${ }^{40}$ This result was not surprising. On 28 July, President $\mathrm{Hu}$ Jintao spoke on the national effort to combat SARS. Besides commending the medical community and Party officials at all levels, $\mathrm{Hu}$ 's focus was on the need to accelerate economic growth and recoup the economic loss suffered during the pandemic. ${ }^{41}$ The risk of wildlife exploitation for future pandemic outbreaks was not mentioned partly because the Party leaders did not want to take a stand on two sets of conflicting findings by the Chinese scientists, i.e., comparing the Hong Kong/Shenzhen findings with the CUA findings. Two months later, civet cats returned to the wildlife markets and restaurants in Guangdong.

In the next 17 years, wildlife trade for the exotic food markets staged a spirited comeback. By the end of 2017, the wildlife industry had become a gigantic business operation with an annual revenue of 520 billion yuan (US $\$ 77$ billion). ${ }^{42}$ Except for the return of SARS in the winter of 2003, there was no consensus among the Chinese scientists on the connection between wildlife trade and pandemic outbreaks. While the wildlife industry and authorities in charge of wildlife paid little or no attention to the danger of zoonotic disease outbreaks, Zhong Nanshan, China's top medical scientist, took the opportunity of attending the National People's Congress in March 2010 to alert the nation on the pandemic risks of wildlife trade. $\mathrm{He}$ even revealed that coronavirus had again been found in wild animals in Hong Kong and Wuhan. Zhong's warning failed to wake up the Chinese authorities. $^{43}$ It was not until the outbreak of COVID-19 that Zhong's warning a decade earlier was revisited.

\section{The Politics of Development and the Trade Resumption}

With the benefit of hindsight, China's reversing of the trade ban after SARS was not surprising. Circumstantial evidence and substantive developments immediately before and after SARS indicated that lifting the trade ban was inevitable. In 
fact, China's prevailing politics of economic transition at the turn of the century pre-destined the reversal of the trade ban.

\subsection{Economic Transition}

By the end of July 2003, there had been signs that the trade ban would not last. In fact, there was no evidence suggesting that the ban was a permanent policy. A permanent trade ban would have run against a major policy change initiated in 1999 by the country's political elites, i.e., an effort to industrialise the country's wildlife production on a more sustainable path. This objective was part of the country's grand development strategy to phase out loss-making State-owned enterprises, to transit the economy out of resource-intensive production, and to make the economy more competitive in the global markets. It was the Party-State's set policy to launch the Chinese economy on a new mode of production. ${ }^{44}$ The wildlife industry was expected to be transformed from a resource-exploitative production into an intensive, high-yielding, conservation-friendly and job-creating industry.

\subsection{A 30-year Plan}

At the turn of the century, the Chinese government saw wildlife production as a rural development project with great growth potentials. In December 1999, at a national wildlife management conference in Beijing, the SFB introduced five major tasks for the 10th Five Year Plan Period (2001-2005) for the wildlife industry. These were nature reserve construction, wildlife habitat preservation, wetland protection, wildlife industry development, and construction of scientific and technological support systems for conservation purposes. ${ }^{45}$ The conference did not happen at the whim of the SFB officials. It was part of the national government's effort to phase out the resource-intensive production model and promote intensification of wildlife farming. To implement the five major tasks, in June 2001 the SFB submitted to the State Planning Commission a long-term plan to expand and intensify wildlife production. Included in the plan were detailed proposals and budget estimates for three different phases (2001-2005; 2006-2010; and 2011-2030). ${ }^{46}$

The plan was great news for wildlife breeders, traders and catering business owners. It even contained proposals on the captive breeding of protected species. Officials in the SFB believed that, by flooding the market with captive-bred wildlife products, illegal hunting would stop. To both the wildlife businesses and SFB, phase one, i.e., 2001-2005, was an important starting point for the 30 -year plan. It was a time for the industry to consolidate, intensify and prepare for an accelerated growth in the second phase (2006-2010) and for sustained development for the rest of the plan period (2011-2030).

The outbreak of SARS in November 2002 was a bolt from the blue. To the wildlife industry, the linkage between SARS and wild animals sold for food was bad news. The livelihood of hundreds of thousands of wildlife farmers was suddenly up in the air. To SFB bureaucrats, the trade ban threatened to derail the 30-year plan that anticipated not only the expansion of the country's wildlife industry, but also the Bureau's budgetary and functional expansion prospects. ${ }^{47}$

\subsection{Rekindling the Momentum}

On 25 June 2003, the CCP Central Committee and the State Council issued a joint "Decision on Accelerating the Development of the Forestry Industry". In this policy directive, wildlife breeding was defined as a "new industry" with the potential to become "a new area of accelerated future growth" for the rural areas, an issue hugely important to the Chinese authorities. ${ }^{48}$ The decision was a reaffirmation by the highest authority of the 30 -year plan. The timing of the decision could not have been more meaningful. With SARS running out of steam towards the end of June, the Chinese government was under increasing pressure from the industry to lift the trade ban. The joint decision by the Party and the State Council served to clear the way for the ultimate policy reversal.

The government's motivation to resume the trade was also reflected in a long-awaited conference held in Sanya, Hainan in March 2004. This long-planned conference on the sustainable development of the wildlife industry organised by the SFB gathered 187 people from national and local administrative agencies, the wildlife industry, TCM producers, traditional musical instrument makers, and academia. The conference reaffirmed the State's decision to push for a "strategic shift" in wildlife production and industry expansion by absorbing 
financial input from enterprises that relied on wildlife products as ingredients or materials. Zhao Xueming, SFB Deputy Director in charge of wildlife, revealed that eight measures would be announced to provide policy incentives to businesses involved in captive breeding. ${ }^{49}$ The conference indicated that transitioning wildlife farming from traditional, scattered, resourceexploitative, and peasant backyard operations to a modern concentrated production was a set policy not to be thrown off course by SARS.

Six months later, the eight measures were included in SFB's Instructions on Promoting Sustainable Development of the Wildlife Industry, a policy document released in September 2004 reaffirming the government's support for a "strategic shift from using animal resources in the wild to using animals that are captive bred". 50 Among the eight policy measures, the Instructions stated that the State would provide breeders with guidance, support and subsidies. To those who were involved in the breeding of protected species such as bears and tigers, the Instructions stated that the government would consider adjusting, i.e., increasing the number of species on the "list of terrestrial wild animals that have been successfully domesticated with the help of mature captive breeding technology", a list that allows commercial trade. Additionally, the Instructions committed government assistance to breeders in their efforts to market and sell their products.

Two other incentives were of special significance to the wildlife industry. The Instructions announced that the government recognised the breeders' right of ownership and right of disposal based on the principle of "he who invests in the industry will own and benefit from it". To critics, this acknowledgement represented a huge victory for the farm owners who feared that their farming operations, endorsed initially by the government, would be arbitrarily prohibited because of a sudden policy change. They demanded that the government acknowledge their ownership rights and right to compensation should a policy change happen. The other incentive, a result of years of lobbying activities by the wildlife breeders, allowed tax breaks, loans and even subsidies to wildlife farms that were also operating in, for example, the TCM market. $^{51}$

The reversal of the trade ban was indicative of the importance the authorities attached to the wildlife industry. In November 2002, China saw the rise of a new generation of political leaders under General Secretary and President $\mathrm{Hu}$ Jintao. While the new leadership was motivated to keep the momentum of fast economic growth, they faced a tough challenge. The reform of the State-owned enterprises launched in $1997 \mathrm{had}$, by the end of 2002, resulted in 28.29 million workers losing their jobs. ${ }^{52}$ Issues of rural underdevelopment, rural unemployment and peasant poverty began to surface. ${ }^{53}$ To Hu Jintao and his associates, the spectre of peasant revolt could not become a realistic threat. Maintaining fast growth was therefore the only way to absorb the laid-off workers, alleviate rural poverty, and defuse rural resentment. The new leaders had a strong reason not to disrupt wildlife production that employed some of the most disadvantaged rural labourers.

\section{Business, Academic and Bureaucratic Interests}

The SARS pandemic and the trade ban posed the first major crisis to the wildlife industry. During the pandemic, the wildlife industry did not sit still. The resumption of the wildlife trade after SARS was as much a government decision as an accomplishment by the wildlife industry that had helped create a narrative on the benefits of wildlife production, used charity to create and influence public opinion, and sponsored research by the country's top wildlife experts. As a non-State actor, the wildlife industry has learned to build relationships with the administrative agencies, legislatures, the media and academia to enhance their lobbying capacity. ${ }^{54}$

\subsection{The Business Interest}

Beyond its behind-the-scene lobbying activities, the industry had long created a narrative about the importance of the industry to conservation, to public health, and economic development. Critics have long questioned the claimed scale and importance of the industry. Thanks to its active promotional efforts, the industry has been acknowledged by the Chinese government as a major contributor to rural development.

\subsubsection{The Narrative}

Since the early 1990s, wildlife businesses had produced an industry narrative that helped frame 
public discourse on wildlife. Representatives of the industry claimed that commercial use of wildlife served the national interests of conservation, public health and poverty reduction. This narrative was adopted by the media and has reinforced the government's positions on wildlife and wildliferelated production. ${ }^{55}$

The industry's narrative has three target audiences. The first is the international community and Chinese critics who are concerned with the impact of commercial operations on wildlife conservation. In 1994, the business interest described its farming operations as conservationfriendly, in response to international condemnation of bear farming. ${ }^{56}$ Since then, the industry has stood by the conservation claim. In 2004, representatives of the bear-farming industry and their supporters in academia and government, for example, converged at the $19^{\text {th }}$ International Congress of Zoology (ICZ) in Beijing to confront international and domestic critics. Liu Jide, founder and CEO of Heibao Pharmaceutical Co., the biggest bear-farm and TCM producer in Northeast China, told the ICZ attendees that wildlife farming served to reduce poaching pressures on animals in the wild. He claimed that the amount of bile extracted from one farm bear a year was equal to the amount collected from more than 200 bears killed in the wild. ${ }^{57}$ Bear farming, according to Liu, was therefore not to be criticised, but should actually be praised for conservation.

Zhou Weisen, owner of Guilin's Xiongsen Bear and Tiger Mountain Village, a tiger farm built in 1993 just before China outlawed the use of tiger bone in TCM, has been a most passionate defender of wildlife farming. To convince international and domestic critics, he showcased his breeding operations to international and domestic visitors. ${ }^{58}$ In an internal discussion in 2015 in the presence of wildlife experts, government officials and conservation specialists, Zhou, Liu and other breeders argued vehemently that they should have the same property and disposal rights with regard to tiger and bear parts as are accorded to breeders of Sika deer, a protected species allowed for commercial breeding and trade. ${ }^{59}$ They demanded the right to trade tiger and bear parts, just as Sika deer farmers have legally been doing. They stood by their position that legal trade promoted conservation.

The second audience is the Chinese public. Representatives of the wildlife industry have promoted wildlife farming as a "life-saving" enterprise because of what they have claimed to be the irreplaceability of wild animal parts in TCM products. "Life-saving" is a powerful claim. It can distort the judgment of even the most scientifically minded Chinese when their loved ones are in adversity, for example, or when the country is hit with a major epidemic. The life-saving claim has apparently been accepted by the Chinese authorities. To fight the COVID-19 pandemic, the Chinese government even joined the wildlife business in promoting a TCM product containing bear bile as a "life-saving" medicine. On 10 March 2020, the Public Health Commission of the People's Republic of China recommended Tanrenqing, a bear-bile drug, to fight COVID-19, a recommendation that caused a strong reaction from critics inside and outside China. ${ }^{60}$ To some critics, the Commission's decision could be used by the industry to call for an end to the wildlife trade ban. ${ }^{61}$

The third audience is the Chinese government. Although China has implemented a so-called "socialist market economy", the market is not yet a fair and equal platform for private businesses. As scholars have long pointed out, the country's reformist State is still the most powerful actor that can impact the profitability and even survival of private enterprises. To mitigate the impact from policy and leadership changes, Chinese businesses have been known to take proactive measures to have their views heard. ${ }^{62}$ Businesses have therefore attached importance to government relations to better defend existing interests, fight for lost interests, and seek new interests. Presenting their commercial interests as national interests is one way to lobby the law-makers and policy-makers. ${ }^{63}$ They have mostly promoted their commercial operations as creating jobs, fighting poverty, saving lives, and an asset to rural development, the top concerns of the Chinese government. ${ }^{64}$ In almost all SFB statements, the wildlife farming industry is recognised for its contribution to rural job creation and poverty reduction. ${ }^{65}$

\subsubsection{Charitable Acts}

To the wildlife industry, charitable acts are the best lobbying activity. In May 2003, the founder and owner of Guizhentang, the biggest bear farm in Fujian, made a high-profile trip to Beijing's Xiaotangshan Hospital, built for treating SARS patients. She brought with her a bear-bile drug reportedly worth 500,000 yuan, and donated the 
unproven drug to the government for use in treating SARS patients. This ostensibly philanthropic act was, admittedly, manifestly designed to advertise bear bile as "life-saving" at a time when the country was facing its biggest public health crisis in this century. ${ }^{66}$ It was also a subtle effort to press for an end to the trade ban. ${ }^{67}$ Despite a few dissenting voices on the motives behind it, the Chinese media and the public were largely silent on this donation. In China, kindness or philanthropic acts are to be praised, not questioned.

Unsurprisingly, the owner of Guizhentang repeated her philanthropic act in April 2020. Her bear-bile drugs were again donated to Hubei province for use in fighting COVID-19. ${ }^{68}$ The Chinese public this time did not remain silent. "Guizhentang was not just promoting bear bile drug as 'life-saving', it was using this donation to make a case for re-opening the wildlife trade", commented Dezhi Yu, director of Beijing's Capital Animal Welfare Association. ${ }^{69}$ In fact, Guizhentang was not alone in donating bear-bile drugs to fight COVID-19. Heibao Pharmaceutical, the biggest bear farm in Northeast China, also donated bear-bile drugs to Hubei. ${ }^{70}$ Their donation was questioned. Bear bile is used in TCM to treat ailments such as eclampsia, epilepsy, sore eyes and swellings. It is also believed to be good for detoxification, purifying the liver, and improving eyesight. ${ }^{71}$ Both SARS and COVID-19 were pandemics that took the global medical community by surprise, so Chinese TCM pharmaceutical companies and TCM researchers could not have developed bear-bile drugs in anticipation of them. Both Guizhentang and Heibao were commended in media reports for their charitable acts in 2003 and 2020. Admittedly, Guizhentang's donation in 2003 did achieve the expected results of increasing Guizhentang's name recognition, its bear-bile drugs, and the wildlife industry as a whole. ${ }^{72}$ The media reports helped drive home the message that TCM products containing wild-animal-sourced components were life-saving. The wildlife industry was to be protected, not banned. ${ }^{73}$

\subsection{Scale and Influence}

Studies on private business lobbying suggest that lobbying effectiveness is proportional to the size of the business concerned. ${ }^{74}$ In 2003, the wildlife industry had some 42,000 farms that produced a revenue of 56.9 billion yuan in 2003 (0.52 percent of China's GDP of 1.1 trillion yuan) ${ }^{75}$ Importantly, it was also part of the rural economy employing several million peasants. This enormous industry called for serious considerations from the Party-State. Guangdong alone had 1,300 breeding farms providing jobs to local farmers and migrant workers. Inland provinces such as Hunan, Jiangxi, Guangxi, Hainan, Hubei, Sichuan and Guizhou attached importance to wildlife production to fight rural poverty. The trade ban reportedly led to a loss of 1 billion yuan in sales revenue to the breeders in Guangdong province alone. ${ }^{76}$ The impact was also felt by hundreds of thousands of transporters, feed traders, veterinary supply dealers, exotic food restaurant owners, and other businesses indirectly connected with the industry.

In 2002, wildlife trade for the country's exotic food market was a booming business. In Guangzhou alone, there were four major wildlife markets supplying the city's exotic food restaurants. These markets and the catering businesses made the city the world's unparalleled "capital of wildlife eating". Xinyuan was the biggest of the four wildlife markets, boasting a daily transaction of 1.9 million yuan and an annual business revenue of 700-800 million yuan. ${ }^{77}$ From a score of stores in the early 1990s, Xinyuan Market had expanded to some 100 stores by the time SARS broke out, trading wild animals of 1,000 different species. This was mainly a wholesale market with stores and stalls that also slaughtered small animals on site for small catering businesses. The catering business in Guangzhou in the years leading up to SARS was booming; it was estimated that some 300 transport trucks loaded with wild animals arrived before daybreak each day. ${ }^{78}$ Hundreds of thousands of Guangdong rural workers' livelihoods depended on the wildlife trade.

By the time SARS broke out in China, wildlife consumption, formerly limited to Guangdong and Guangxi, had spread to the rest of the country as a result of aggressive promotion by the traders and catering businesses. Nationally, China's exotic food catering industry in 2002 was an eight-billion-yuan business. ${ }^{79}$ In Shanghai in 2002, 16,000 of its 20,000 restaurants reportedly sold more than 1,000 tons of snakes, 50 tons of frogs, and 10 tons of birds a year. In Shenzhen, the 800 local restaurants processed some 15-20 tons of wild animals every day. Snakes accounted for 10 tons of the daily sale. Civet cats were one of the species found to carry the SARS coronavirus; they were a popular dish on the menu of restaurants in Guangzhou and Hong Kong 
which both reportedly consumed 86,000 civet cats a year. Nationwide, 6,000 tons of snakes were consumed (some 10 million snakes). ${ }^{80}$

Exotic foods were a tourist attraction of Guangdong and contributed significantly to the revenue of the local catering industry. Tourist agents used exotic foods to attract visitors to the province. A pangolin that was purchased from a trader for several hundred yuan could fetch up to 10,000 yuan when served as food in Guangdong. ${ }^{81}$ Wildlife traders in Viet Nam were paid eight yuan only by Chinese traders for every 500 grams of monitor lizard. In Guangdong, the same amount of monitor meat would go for up to 80 yuan and fetch 150 yuan when it was served in a restaurant. ${ }^{82}$ Similarly, 500 grams of civet cat meat could go up from 30 yuan at a breeding farm to 500 yuan after it was placed on a dinner plate. ${ }^{83}$ Steamed pangolin meat for four people could cost 5,000-6,000 yuan in Guangdong. ${ }^{84}$ According to a Guangzhou catering business owner, hotels and restaurants would lose customers if they did not have exotic meats on their menus. It was not a secret that restaurants serving wild animal meats had profits two or three times bigger than those that did not. The trade ban caused revenues in Guangdong's catering business to drop in the first half of 2003. For example, Guangzhou saw a 30 percent drop in catering business revenue compared with the corresponding period in 2002. ${ }^{85}$

Businesses started their behind-the-scenes lobbying in April when the trade ban was imposed by the national government. Local forestry bureaus had been pressured to send industry complaints and "grievances" to the national government. ${ }^{86}$ The SFB had also received anonymous petitions asking for the reopening of the trade, a source of income for millions of rural workers. ${ }^{87}$ Such anonymous petitions often seemed to come in at just the right moment, leading critics to speculate on possible coordination between petition submitters and officials in the administrative agencies.

\subsection{The Academics}

In mid-June, the wildlife industry had a reason to be hopeful that the days of the trade ban were numbered. The CUA in Beijing announced on 19 June 2003 that its research team failed to find the SARS virus in the 732 samples of captive-bred and wild-caught animals collected from seven regions of the country. The study overthrew the earlier findings released on 23 and 24 May by other Chinese scientists. ${ }^{88}$ More importantly, the new findings provided the wildlife business interest much needed evidence that SARS should not be blamed on captive-bred animals and that the breeders and traders deserved to have their business operations restored.

The CUA findings were questioned by a scientist from the HKU who led the research work that identified the SARS virus in three wild animal species. ${ }^{89}$ The findings of the HKU and the Shenzhen CDC were later published in Science, a peer-reviewed journal (2003, Oct. 10:276-278), and have since been cited more than 1,600 times worldwide. The research team of the HKU was able to re-confirm the presence of the SARS virus in wild animals in their field trips to Guangdong made in September, October, November and December 2003. It was the HKU researchers who notified the national government in January 2004 of their findings that led to resolute actions taken by the authorities to cull all civet cats from the markets. ${ }^{90}$ The HKU team's finding was understandably unpopular among the wildlife traders and interests that had a stake in the lifting of the trade ban on civet cats and all other wild animals. What was perhaps embarrassing to the country's wildlife management authority was that the HKU's finding challenged the wisdom of the SFB that had allowed civet cats, among 53 other species, to be farmed, traded and consumed.

However, the HKU's follow-up findings were too late. The CUA findings seem to have been accepted in June 2003 by the wildlife industry and the SFB. In retrospect, the CUA findings provided the SFB with the scientific evidence it needed to support the decision to lift the trade ban. The CUA findings attracted immediate and much uncritical media coverage when they were announced in Beijing by the University's president, a celebrity scientist. Reports from sympathetic media claimed that the CUA findings helped "restore the reputation of civet cats". 91

Like other businesses, the wildlife industry supports academic research. While the timing of the CUA research might coincide with the Chinese government's decision to lift the trade ban, the wildlife business interest making special efforts to forge partnerships with academic institutions has raised eyebrows. Guizhentang sponsored and built inside its premises a "Post-doc Research Work Station" and a "Working Station for Experts from the National Academy of Engineering and the 
National Academy of Sciences". Benefiting from Guizhentang's support is Ma Jianzhang, the country's "Father of Wildlife Resource Use" and academician of the National Academy of Engineering. ${ }^{92}$ On 3 November 2010, Professor Ma attended the opening ceremony at Guizhentang for a work station devoted to joint research on creating standards for bear farming. ${ }^{93}$ Professor Ma's joining the "work station" inside Guizhentang attracted much criticism. A Tsinghua University professor asked if Professor Ma should be called a "supporter of bear farming". 94 As the "godfather" of China's "utilisation" experts, Professor Ma helped create China's first "wildlife resources college" at Northeast China University of Forestry in Harbin.

As the country's top wildlife expert, Ma chaired countless expert committees set up by the SFB to evaluate a wide range of wildlife farming and other wildlife utilisation projects. As a result of his chairing two recent expert committees that approved captive breeding of rhinos as well as the issuance of hunting permits to foreign hunters, Ma was again criticised for supporting wildlife exploitation at a time when wildlife conservation remained a challenge in the country and rhino poaching was intensifying. The critics asked if Professor Ma was truly an independent scientist due to the fact that much of his research work was funded by the SFB and he was connected with the wildlife business interests. $^{95}$ Admittedly, government funding of research projects is common across the world. Conducting research work with government funding does not necessarily disqualify a scholar's work as biased. It is the consistency of the research work or professional opinions that support wildlife utilisation that raises eyebrows among the critics.

In China, there are two groups of academics who support the use of wildlife. The first group believes that commercial development of wildlife is the best approach for wildlife conservation, and argues that conservation would be pointless if wildlife were not utilised for economic purposes. ${ }^{96}$ These pro-utilisation scholars led by Professor Ma have been most influential in China's wildlife policy-making. ${ }^{97}$ A second group of scholars can be referred to as "culture defenders". Represented by a late Academician of the National Academy of Engineering and a TCM expert, members of this group are adamant that China's wildlife industry has been vilified in the West. They see foreign criticism as an assault on the Chinese culture and the Chinese government. In their opinion, China should stand firm in defending its industries based on what they called Chinese culture and tradition. They see foreign criticism of Chinese wildlife farms as either a clash of civilisations or Western cultural imperialism in the name of animal rights. ${ }^{98}$ To them, defending wildlife trade and consumption means defending China's pride, traditions and national interest. ${ }^{99}$ These two groups of scholars have, since the early 1990s, been the most vocal supporters of wildlife utilisation.

\subsection{The Bureaucratic Interest}

In August 2003, the SFB announced the decision to lift the trade ban. As the country's national agency responsible for managing and supervising terrestrial wildlife resources, the SFB "organizes and conducts terrestrial wildlife resource surveys, drafts and adjusts the state key protection list of wild animal and plant species, directs the rescue and breeding of terrestrial wild animals and plants, restores habitats, monitors the sources of epidemics, supervises and manages the collection, hunting, breeding and trading of terrestrial wild animals and plants, and supervises and manages the import and export of wild animals and plants". ${ }^{100}$ If the trade and farming operations were banned, many of the functions of the SFB would be adversely impacted.

\subsubsection{Budget Increase}

The SFB's budget has seen an exponential increase with the expansion of its regulatory authority over the country's wildlife businesses. In June 2001, the SFB's long-term plan for wildlife protection was approved by the then State Planning Commission. This long-term plan was laid out in a more detailed SFB directive that was released in September 2004. What followed was a steady bureaucratic expansion of the nation's wildlife management agency, an expansion that was necessitated to better manage the anticipated intensification and growth of wildlife farming operations. Indicative of this bureaucratic expansion was a drastic SFB budget increase in the following years. Between 2001 and 2009, the Bureau's annual budget increased 409 percent, from 636 million yuan in 2000 to 3.2 billion yuan in 2009. Besides the budget increase, the coverage of State funding was also expanded to all existing and new areas of the Bureau's responsibility, including wildlife resource 
conservation and captive breeding. ${ }^{101}$ In 2019, the total budget of the SFB reached 8.5 billion. ${ }^{102}$

\subsubsection{Bureaucratic Expansion for Wildlife Utilisation}

Provincial forestry bureaus have also expanded. By the end of 2017, 1,751 "Wild Animal and Plant Management Stations" (WAPMS) had been created in 33 provinces and province-level regions. ${ }^{103}$ However, the wildlife conservation responsibility of these "stations" has been questioned due to the fact that the provinces with the most stations were also those with the most incidences of wildlife crime. A recent study of 1,552 wildlife crimes found that Hunan, Jiangxi, Shanxi and Hubei, provinces with the most stations, had the biggest number of cases involving the illegal hunting of endangered species, and with Xinjiang and Heilongjiang, also accounted for the biggest number of cases of illegal hunting in general. ${ }^{104}$ This is not surprising. The WAPMS were set up with two major responsibilities: to stop illegal hunting and to manage captive breeding. They have, however, worked harder to help the breeders than to prosecute wildlife crimes. Some have reportedly gone so far as to help whitewash acts that violate laws and regulations. ${ }^{105}$

Unsurprisingly, while provinces with more WAPMS were not more successful in curbing wildlife crimes, they accomplished more in captive breeding. Jiangxi, an inland province with 212 stations, had by the end of 2018 declared a wildlife farming revenue of 10 billion yuan. ${ }^{106}$ Hubei with 105 stations had 500 wildlife breeding farms with an annual revenue of 300 million yuan in 2016. ${ }^{107}$ Heilongjiang, with 157 stations, produced a wildlife farming revenue of 2.5 billion yuan in $2013 .{ }^{108} \mathrm{In}$ Zhejiang province, the number of wildlife breeding farms increased from 276 to more than $1,500 .{ }^{109}$ Hunan in Central China had 258 stations in 2017, the most among the provinces. Hunan's wildlife farming expansion was also most breathtaking. In 1997, there were 193 breeding farms with farming permits. In 2011, 700 breeding farms received or were in the process of receiving permits. ${ }^{110}$ Bamboo rats and snakes were reportedly two of the most farmed species. It was noted, however, that in Changsha, the provincial capital, two thirds of the 10 tons of snakes sold daily were wild-caught. ${ }^{111}$ This suggests that these stations have failed to serve as outposts of wildlife protection, although their officials are known to defend wildlife farming when it is criticised. One of the most vocal opponents of the trade ban imposed in January 2020 was a WAPMS chief in Guizhou. ${ }^{112}$

\subsubsection{Regulatory Failure}

There is no shortage of national and local forestry bureau officials acting as spokespersons for the wildlife business interest. In response to the Chinese government's decision to revise the Wildlife Protection Law with the aim to restrict wildlife trade for the exotic food market, a provincial forestry bureau director openly questioned the necessity for revising the law. Across the country, there are 106 associations of specialised farming. ${ }^{113}$ These associations provide a strong voice on behalf of the wildlife breeders. The China Association of Wildlife Conservation, under the SFB, is supposedly a defender of wildlife and conservation. Its close relations with the wildlife industry have raised eyebrows. The Association's recent Board of Directors included TCM pharmaceutical company managers, a CEO of a hunting gun manufacturer, and a CEO of one of China's biggest entertainment companies that uses terrestrial and marine animals for performances. To critics, it would be asking too much to expect the government administrative agencies, the WAPMS, and the Association to speak for wildlife protection. ${ }^{114}$

Prior to the appearance of COVID-19, China's wildlife markets were in a state of lawlessness. This was partly caused by the fact that the country's market regulation authorities were often overwhelmed with inspection work of other daily necessities such as pork, chicken or aquatic food products. Besides, the country's wildlife regulatory authorities contributed to the market lawlessness. Local forestry bureau officials were known to patronise catering businesses serving wild animal meat. In 2012, protected monkeys in Jiangxi were constantly poached and served in restaurants designated for official catering purposes. Those who were responsible for wildlife protection reportedly participated in illegal hunting. ${ }^{115}$

In Guangxi, a province whose pangolins in the wild are near extinction, local officials reportedly served pangolin meat to visitors on official duties to the province. In one case, a pangolin feast was held in the office of local Guangxi officials. ${ }^{116}$ Critics asked how the Chinese people could entrust the country's wildlife to forestry bureau officials. To the critics, there is no reason to believe what happened 
in Guangxi was an isolated case of Chinese local officials holding the State laws in contempt. A deputy chief of a local forestry bureau in Jiangxi admitted having consumed different kinds of wild animals, including pangolins presented to him by his subordinates. 117 In Northeast China, wild-caught forest frogs were served by provincial officials at a dinner in honour of visiting officials from Beijing. ${ }^{118}$ By consuming wild animals at official catering events, the Guangxi and Jilin officials were not only supporting wildlife farming, but also endorsing activities involved in selling illegally caught wild animals as captive-bred individuals. In China, attempts to breed pangolins and forest frogs have not been successful.

Clearly continuing the trade ban imposed in order to contain SARS ran counter to both commercial and bureaucratic interests. The wildlife industry and the forestry administrative agencies were motivated to end the trade ban. In one ranking of China's national government spending, the SFB's annual budget in 2010 shot up to 10th position among the 31 national government agencies. ${ }^{119}$ For the sake of its bureaucratic interest, the SFB was incentivised to lead efforts to end the trade ban.

\section{Conclusions}

China's lifting of the trade ban in August 2003 was predestined. This policy reversal was as much a result of the prevailing politics of China at that time as a result of years of lobbying efforts by the wildlife industry. A study of policy change in China, a Leninist Party-State, must take into account the priorities of the Party leadership at the time of policy-making. China at the turn of the century was at a crossroads. The Party's set policy of elevating the national economy from the old and resource-exploitative model of production to a sustainable development model offered the wildlife industry a good opportunity to expand and intensify. The Party's policy guidelines also gave the national and local forestry bureaus a golden opportunity to seek a budgetary expansion in anticipation of greater regulatory responsibilities. The SARS pandemic and the trade ban were an unexpected threat to both the industry and the administrative agencies.

While policy-making is still monopolised by the Party-State and its administrative bureaucrats, non-State actors have gained space to define, defend and seek their interests. A non-State actor that can impact employment, growth and poverty reduction is strategically much better positioned to have its voice heard in policy-making. The wildlife industry was such an actor. Launched in the 1980s as a key player in reducing poverty, it had long built a case for its own defence through a narrative that aligned its commercial endeavours with the national efforts of conservation, public health and poverty reduction. The industry has long believed that it is part of the Party-State and should be supported as such. ${ }^{120}$ With this conviction, the industry has been an active lobbying group through frequent contacts with the policy-making agencies, the media and the academic community supporting wildlife utilisation. Importantly, the reversal of the trade ban in August 2003 was not entirely the result of the direct lobbying activities of the industry. Rome was not built in a day. The reversal of the trade ban in August 2003 was the result of a combination of factors that included the prevailing politics, the Party-State's set policy objectives for the economy, the industry's narrative that had been advanced prior to SARS, and its strengthening relationships with academics and the media.

Will China reverse the existing trade ban imposed to contain the COVID-19 pandemic? Has China learned a lesson despite the flowing of many "conspiracy theories" diverting attention from the country's wildlife trade and wildlife markets? We have seen different Chinese reactions to the COVID-19 pandemic since 1 January 2020. The trade ban, issued originally by three administrative agencies at cabinet level, was elevated as a national legislative decision. Chinese President Xi Jinping made two public remarks on the need to stop wildlife trade for the exotic food market. There seems to be greater political determination to continue the trade ban with the help of a revision to the Wildlife Protection Law. A recent Chinese study of public reactions to the country's wildlife trade ban shows overwhelming Chinese public support for ending the trade and consumption. ${ }^{121}$ While in 2003, the question of whether wildlife exploitation could breed another pandemic was not a concern, preventing future pandemics tops the consideration of the Chinese leadership in 2020.

Unsurprisingly, China's wildlife business interest and the coalition have not remained silent; they are fighting for their interests. It can be expected that the Chinese authorities will make some concessions, such as allowing breeding operations for fur, TCM, 
display and laboratory use to continue while keeping the ban on breeding for the exotic food market. The Chinese government has made concessions to business interests by allowing 16 wild animals to be included in a recently promulgated "Livestock Catalogue" for commercial use. ${ }^{122}$ Yet, the wildlife trade and consumption ban has continued. Today, the wildlife industry accounts for a much smaller proportion of China's gigantic GDP compared with that in 2003. There is, therefore, less reason for the Chinese government to lift the trade ban. Wildlife breeding operations for fur, for TCM use, for display, for pet markets and for laboratory use, however, are similar to wildlife operations for the exotic food markets, in that they have also featured concentrated feeding operations in unnatural conditions. They, too, can become breeding grounds for pandemic outbreaks. It is important that countries with wildlife breeding programmes and transboundary wildlife trade rethink the cost-effectiveness of continuing the wildlife industry.

\section{Endnotes}

\footnotetext{
${ }^{1}$ For an overview of the existing scientific findings and the speculative theories on the outbreak of the COVID-19 pandemic, see Orenstein, R. 2020. Wildlife Markets and COVID-19. Washington DC: Humane Society International. Available at https://www.hsi.org/wp-content/uploads/2020/04/Wildlife-

Markets-and-COVID-19-White-Paper-FINAL-6-Apr-2020.pdf.

2 Ma Jianzhang et al. 2017. A Report of the Strategy of Sustained Development of China's Wildlife Industry: 2016, at 102. National Academy of Engineering.

3 King-lun Ngok. 2002. "Law-making and China's Market Transition: Legislative Activism at the Eighth National People's Congress". Problem of Post-Communism March/April: 23-32.

4 For information on the policy-making hierarchy in the People's Republic of China, see Lieberthal, K. and Oksenberg, M. 1988. Policy Making in China: Leaders, Structures, and Processes, at 35-41. Princeton NJ: Princeton University Press.

5 Lieberthal, K. 2004. Governing China: From Revolution through Reform, at 103-109. New York: W.W. Norton \& Company.

6 Ibid., at 135-138; Zhang Guangyou. 1995. Wan Li in 1975-1986, at 147-213. Hong Kong: Qiwen Books.

7 Tanner, M.S. 1994. "The Erosion of Communist Party Control over Lawmaking in China”. The China Quarterly 138: 381-403.

${ }^{8}$ The National People's Congress, "Some explanations of the revised draft of the Wildlife Protection Law of the People's Republic of China" [in Chinese]. Available at http://www.npc. gov.cn/zgrdw/npc/lfzt/rlyw/2015-12/31/content_1958176.htm.

${ }^{9}$ Conversation with a visiting staff member of the Committee of Environment and Natural Resource Affairs of the National People's Congress of China, 21 August 2015, Washington DC, US.
}

${ }^{10}$ See for example, Liew, L.H. 2004. "Policy elites in the political economy of China's exchange rate policymaking". Journal of Contemporary China 13(38): 21-51.

11 Jiang Yong. 2006. "It calls for vigilance on the increasingly acute problem of bureaucratic interests of the administrative agencies of the central government" [in Chinese]. Liaowang, 10 October. Available at http://news.cctv.com/china/20061010/1024 61.shtml.

${ }^{12}$ Wen-Hsuan Tsai. 2015. "A unique pattern of policymaking in China's authoritarian regime". Asian Survey 55(6): 1093-1115; see also, Tanner, M.S. 1995. "How a bill becomes a law in China: stages and processes in lawmaking". The China Quarterly 141:39-65.

${ }^{13}$ Supra, note 11.

14 See, for example, Liu Chunrui. 2014. "Preventing the institutionalization of bureaucratic interests in law-making at the People's Congress" [in Chinese]. Beijing News, 14 January. Available at http://www.bjnews.com.cn/feature/2014/01/14/3017 83.html.

15 Waikeung Tam and Dali Yang. 2005. "Food safety and the development of regulatory institutions in China". Asian Perspective 29(4): 5-36; see also Tu Xiaofang. 2002. "The impact of bureaucratic interests on government behaviors". Journal of Chinese Administrative Management 10: 16-18.

16 Supra, note 11.

${ }^{17}$ See for example, Zhang, X. and Jennings, E. 2009. "Public participation in environmental policymaking in China: a case study". Paper produced for Midwest Political Science Association Conference; see also Wong, N.W.M. 2016. "Advocacy coalitions and policy change in China: a case study of anti-incinerator protest in Guangzhou". International Journal of Voluntary \& Nonprofit Organizations 27(5): 2037-2054.

18 Tian Zhilong and Gao Haitao. 2006. "Business lobbying and its ethical criteria in China". Chinese Journal of Management 3(5): $560-568$.

${ }^{19}$ Balla, S.J. 2017. "Is consultation the 'new normal?': Online policymaking and governance reform in China". Journal of Chinese Political Science 22: 375-392.

${ }^{20}$ Schubert. G. and Heberer, T. 2017. "Private entrepreneurs as a 'strategic group' in the Chinese polity". China Review 17(2): 95-122.

21 Dickson, B.J. 2003. Red Capitalists in China: The Party, Private Entrepreneurs, and Prospects for Political Change. Cambridge: Cambridge University Press.

${ }^{22}$ Kennedy, S. 2005. "China's Porous Protectionism: The Changing Political Economy of Trade Policy". Political Science Quarterly 120(3): 407-432. See also Tu Xiaofang, supra, note 15.

${ }^{23}$ Deng, G. and Kennedy, S. 2010. "Big business and industry association lobbying in China: The paradox of contrasting styles". The China Journal 63: 101-125.

${ }^{24}$ Supra, note 22; and ibid. See also Xia Xiang. 2010. "A preliminary discussion of lobbying activities in corporate government relations management". Journal of Chinese Science and Technology 3: at 169.

${ }^{25}$ For a full account of the efforts that led to the discovery of the SARS coronavirus, see 2020. "Professor Guan Yi's account: how his lab at Hong Kong University was able to pinpoint the host of SARS in 2003" [in Chinese]. San Lian Life Weekly, 21 January. Available at https://xw.qq.com/cmsid/20200121A0JRQH00.

${ }^{26}$ Guan, Y., Zheng, B.J., He, Y.Q. et al. 2003. "Isolation and characterization of viruses related to the SARS coronavirus from animals in Southern China". Science 302(5643): 276-278. 
27 Dong Jun. 2003. "Research found that SARS virus came from wild animals, not from livestock and pets" [in Chinese]. Xinhua News Agency, 24 May. Available at http://www.cas.cn/zt/ kjzt/fdgx/zjpl/200305/t20030526_1710230.shtml.

28 Xinhua News Agency. 2003. "The provincial government of Guangdong issues an emergency notice strictly controlling wildlife trade and breeding" [in Chinese]. Xinhua News Agency, 26 May. Available at http://www.cas.cn/zt/kjzt/yw/rzdy/2003 06/t20030605_1711414.shtml.

29 The State Forestry Bureau. 2003. "The State Forestry Bureau and State Industrial and Commercial Administration Bureau Emergency Notice on Strictly Controlling Wildlife Trade, Use and Breeding". 29 April. Available at http://www.chinaacc. com/new/63\%2F70\%2F2006\%2F2\%2Fzh1 17354715172260023 510-0.htm.

30 Speech by the head of the Industrial and Commercial Administration [in Chinese]. Available at http://www.china lawedu.com/falvfagui/fg22016/44679.shtml.

31 Speech by the head of the State Forestry Bureau [in Chinese]. Available at http://www.chinalawedu.com/falvfagui/ fg22016/44679.shtml.

${ }^{32}$ See, e.g., Xing Tingxi. 2003. "The impact of SARS on animal farming and solutions". Animal Feed Industry 24(11): 4-6.

33 Conversation with Jill Robinson, CEO and Founder of Animals Asia Foundation, San Francisco, September 2002.

${ }^{34}$ International Fund for Animal Welfare, 1998. Public Opinion Survey on Animal Welfare. Beijing: BMS \& Associates, Inc.

35 The State Forestry Bureau. 2003. "Notice on the need to carry out a strict ban on illegal hunting and trade in terrestrial wild animals in line with the new situation" [in Chinese]. SFB policy document issued on 3 June. Available at http://www.for estry.gov.cn/portal/main/govfile/13/govfile_1071.html?f_ww=1.

${ }^{36}$ Electronic interview with a former turtle farmer of Jiangxi Province, 14 March 2020.

37 Editorial. 2003. "Time to overthrow the 'false charges' against the civet cats". Journal of Special Economic Animals and Plants 8: at 35.

38 Xinhua News Agency. 2003. "Guangdong's emergency notice: placing a strict control over the trade, utilization and captive breeding of wild animals" [in Chinese]. Xinhua.com, 27 May. Available at http://www.china.com.cn/zhuanti2005/txt/ 2003-05/27/content_5336378.htm.

${ }^{39}$ Xinhua News Agency. 2004. "Consumption or Culling: The fate of civet cats and other wild animals since 2003" [in Chinese]. Xinhua News Agency, 8 January. Available at http://www.people. com.cn/GB/huanbao/1074/2285764.html.

40 The State Forestry Bureau. 2003. "The State Forestry Bureau Notice on Releasing the List of 54 Terrestrial Wild Animals with Mature Breeding Technology such as Sika Deer for Commercial Use and Breeding" [in Chinese]. 4 August. Available at http://www.wendangku.net/doc/9138dd42b307e871 01f69624-2.html.

${ }^{41}$ China News Service. 2003. "In reviewing the struggle with SARS, Hu Jintao spoke on eight experiences" [in Chinese]. China News Service, 28 July. Available at http://www.china news.com/n/2003-07-28/26/329242.html.

42 Supra, note 2, at 102-103.

${ }^{43}$ Wang Pu et al. 2010. "Zhong Nanshan: more than $60 \%$ of the new diseases came from animals" [in Chinese]. Yangcheng Evening News, 3 March. Available at https://news.qq.com/a/ 20100303/002895.htm.
44 For a detailed exposition of China's economic transformation at the turn of the century, see Cheng Xiaonong. 2003. "A new look at the Chinese economy: motivation of growth and results" [in Chinese]. Modern China Studies 1. Available at https://www.modernchinastudies.org/us/issues/past-issues/80-mcs -2003-issue-1/1269-2012-01-06-09-16-39.html. See also supra, note 5, at 269-270, and 282-285.

$45 \mathrm{Li}$ Diqiang. 2000. "A brief account of the "National Wildlife Management Work Conference". Journal of Biodiversity (shengwu duoyang xing) 2: 207.

${ }^{46}$ State Forestry Bureau. 2001. "A General Outline and Plan for the Protection of Wild Animal and Plant Species and for the Construction of Nature Reserves" [in Chinese]. Available at http://www.forestry.gov.cn/uploadfile/main/2010-11/file/201011-26-b2588ec7594b41f7a1a96e9990c3fd2d.pdf.

47 Conversation with a SFB official on 19 August 2004 in Beijing, China.

${ }^{48}$ CCP Central Committee and the State Council. 2003. "The Central Committee of the Chinese Communist Party and the State Council Decision on Accelerating the Development of Forestry Industry" [in Chinese]. 25 June. Available at http://www.gov.cn/ gongbao/content/2003/content_62358.htm.

49 China Musical Instrument Association Information Network. 2019. "A national conference on the sustainable development of wildlife resources was just held" [in Chinese]. China Musical Instrument Association Information Network, 26 December. Available at http://www.unmwi.com/qita/30915. html.

50 State Forestry Bureau. 2004. "State Forestry Bureau Instructions on Accelerating a Sustained Development of Wildlife Industry" [in Chinese]. 9 September. Available at http://www.forestry.gov.cn/main/4818/content-796873.html.

${ }^{51}$ Ibid.

52 China Statistical Bureau. 2005. China Labor Statistical Yearbook: 2005, at 162-163. Beijing: China State Statistical Press.

53 Gao Guozhong. 2009. "Li Changping's petition to Premier Zhu in 2000: The peasants are bitter, the countryside is impoverished, and the rural economy is dangerous" [in Chinese]. Liaowang Dongfang Weekly News, 10 September. Available at http://news.ifeng.com/special/60nianjiaguo/60biaoz hirenwu/renwuziliao/200909/0910_7766_1342837.shtml.

${ }^{54}$ Xia Xiang, supra, note 24.

55 Beijing Review. 1994. "Commercial raising saves bears", at 34. Beijing Review, 7-13 March.

56 The article "Commercial raising saves bears" was published in English, in the country's official English-language journal Beijing Review, for international readers to understand bear farming and its alleged benefits.

57 The author was a panellist on the "Bear Farming Panel" and served as the translator for Mr Liu when he delivered his speech in Chinese, 23-27 August 2004, in Beijing.

58 Nowell, K. and Xu, Ling. 2007. Taming the Tiger Trade: China's Markets for Wild and Captive Tiger Products since the 1993 Domestic Trade Ban, at 9. A TRAFFIC East Asia report. Hong Kong: TRAFFIC East Asia.

59 Zhou and Liu's speech in an internal consultation session sponsored by a State Council research centre in early 2015.

${ }^{60}$ For information on the inclusion of Tan Re Qing, a bear-bile-based TCM injection, in the list of drugs to fight COVID-19, see Fobar, R. 2020. "China promotes bear bile as 
coronavirus treatment, alarming wildlife advocates". National Geographic, 25 March. Available at https://www.national geographic.com/animals/2020/03/chinese-government-promotesbear-bile-as-coronavirus-covid19-treatment/.

${ }^{61}$ Author's interview with Qin Xiaona, founder of the Capital Animal Welfare Association, 28 May 2020.

${ }^{62}$ For leadership change and impact on business operation in China, see Zhu Jiangnan and Dong Zhang. 2017. "Does corruption hinder private businesses? Leadership stability and predictable corruption in China". Governance: An International Journal of Policy, Administration and Institutions 30(3): 343-363. For information on the efforts of private enterprises to reduce operational cost because of government policy change, see Li Hongbin, Meng Lingsheng and Zhang Junsen. 2006. "Why do entrepreneurs enter politics? Evidence from China". Economic Inquiry 44(3): 559-578.

${ }^{63}$ Xia Xiang, supra, note 24.

${ }^{64}$ Speeches of wildlife business owners at the same internal consultation session sponsored by a State Council research centre in early 2015.

${ }^{65}$ See, for example, State Forestry Bureau. 2004. "Directive on Promoting a Sustainable Development of Wild Animal and Plant Production" [in Chinese]. 9 September. Available at http://www.forestry.gov.cn/sites/main/main/gov/content.jsp?TID= 1079.

66 Kang Jianhai. 2012. "The birth of a million yuan worth advertisement: an extraordinary planning at an unusual time" [in Chinese]. Available at http://blog.sina.com.cn/s/blog_a2da8e63 01010c4d.html.

67 Supra, note 47

$68 \mathrm{Ai}$ Ta. 2020. "Really, donating bear bile drug to fight COVID-19? Please stop under-estimating the intelligence of the Chinese people!" [in Chinese]. A commentary on Guizhentang's donating untested bear-bile drug to Wuhan for treating COVID-19 patients, 29 February. Available at https://baijiahao. baidu.com/s?id=1659807975116988832\&wfr=spider $\&$ for $=p c$.

69 Author's interview with Dezhi Yu, director of the Capital Animal Welfare Association, 1 June 2020.

${ }^{70}$ Qu Jing. 2020. "Never relax in the fight against COVID-19: Heibao donates additional drugs worth 1 million yuan" [in Chinese]. Heilongjiang Morning News, 16 March. Available at https://k.sina.cn/article_2305840117_897053f501900qfbq.html? from $=$ news\&subch=onews.

${ }^{71}$ Feng Yibin et al. 2009. "Bear bile: dilemma of traditional Chinese medicinal use and animal protection". Journal of Ethnobiology and Ethnomedicine 5. Available at https://ethn obiomed.biomedcentral.com/articles/10.1186/1746-4269-5-2.

72 Supra, note 66.

73 Supra, note 69.

${ }^{74}$ See for example supra, note 23.

75 State Forestry Bureau. 2004. "The Outline of China's Forestry Industry Development Plan: 2004-2010" [in Chinese]. Available at https://ishare.iask.sina.com.cn/f/3WChTgkRGvn. html.

76 Yang Wenxing. 2003. "Special poultry breeders are in financial difficulties because of SARS" [in Chinese]. Shantou Daily, 17 July. Available at http://news.sina.com.cn/c/200307-17/13191362239.html.

77 Supra, note 32; see also, Yang Qifei. 2020. "Why cannot we get rid of wildlife consumption 17 years after SARS?" [in Chinese]. nbd.com.cn, 7 March. Available at http://www.nbd.com. cn/articles/2020-03-07/1414597.html.
78 Life Weekly. 2004. “An investigation of Guangdong's wildlife consumption" [in Chinese]. Life Weekly, 3 February. Available at http://www.lifeweek.com.cn/2004/0203/7883.shtml.

${ }^{79}$ Supra, note 46.

${ }^{80}$ Supra, note 32; see also, Yang Qifei, supra, note 77.

$81 \mathrm{He}$ Shi and Deng Yaman. 2020. "From SARS to COVID-19: why was it so difficult to ban wildlife consumption that has given rise to deadly epidemics?" [in Chinese]. China Economic Weekly, 17 February. Available at http://app.ceweekly. $\mathrm{cn} /$ ?app $=$ article $\&$ controller $=$ article $\&$ action $=$ show $\&$ contentid $=286$ 077.

${ }^{82}$ Supra, note 78.

${ }^{83} \mathrm{Hu}$ Yazhu and Chen Qinghao. 2007. “An undercover investigation of Guangzhou's wildlife markets: from civet cats that were connected with SARS to "red-braised civet cat meat" [in Chinese]. Nanfang Daily, 8 November. Available at http://news.cctv.com/society/20071108/102040.shtml.

${ }^{84}$ People's Daily. 2006. "Guangdong: seeing the return of civet cats and other wild animals to the exotic food restaurants, are we forgetting the pains of SARS" [in Chinese]. People's Daily, 15 November.

${ }^{85}$ Zhong Guodong. 2003. "Guangzhou's catering businesses struggled to stay alive during the SARS" [in Chinese]. China Business Operation News, 27 May. Available at https://www. tech-food.com/news/detail/n0014040.htm.

${ }^{86}$ Gao Guozhong. 2004. "What did the reversal of the trade ban on civet cats tell us?" [in Chinese]. Liaowang Dongfang Weekly News, 13 January. Available at http://news.sina.com.cn/c/2004-0113/14242621042.shtml.

${ }^{87}$ For example, the SFB reported receiving petitions from anonymous sources on lifting the domestic trade ban on tiger and rhino parts; see supra, note 58.

${ }^{88}$ Supra, note 37.

89 Supra, note 25.

${ }^{90}$ Ibid.

91 Song Fangchan. 2003. "China University of Agriculture restores the reputation of civet cats who do not have SARS virus" [in Chinese]. China News.com, 20 June. Available at http://www.chinanews.com/n/2003-06-20/26/315998.html.

${ }^{92}$ Guizhentang. "An introduction to Guizhentang" [in Chinese]. Available at http://www.gztxd.com/home/NewsDetail/42.

93 Fujian Sina.com. 2010. "Guizhentang opens a "working station' for academicians" [in Chinese]. Fujian sina.com, 3 November. Available at http://fj.sina.com.cn/business/2010-1103/1739352.html.

94 Jiang Jinsong. 2011. "What does it take for an expert evaluation committee to stay credible?" [in Chinese]. Xinjing News, 10 September. Available at http://news.ifeng.com/ opinion/society/detail_2011_09/10/9095368_0.shtml.

${ }^{95}$ See for example, Zhang Jianfeng, 2011. "Ma Jianzhang: Giving hunting permits to foreign hunters is for protecting wild animals in China" [in Chinese]. Nanfengchuang (South Wind Window), 13 September. Available at http://www.lknet.ac.cn/ news/20110915120000FmgXghnP-V5GjenzFQx 1C22EASOXqJ 8DgzmGy5-RFH7aF2FGUM8wK92JwrPD7r0J.htm.

${ }^{96}$ See for example, Ma Jianzhang, Chao Liancheng and Luo Zexun. 1985. "A discussion of the dialectical relations among protection, domestication and hunting of wild animals". Journal of Northeast-Eastern Forestry College 13(1): 70-78.

${ }^{97}$ Pan, Z., Zhang, W. and Zhou, X. 2001. "The necessity for developing the wildlife industry" [in Chinese]. Journal of Northeast Forestry University 5: 58-59. 
98 Li Lianda. 2012. "On bear farming" [in Chinese]. China Traditional Medicine News, 17 February. Available at http://www.xinfajia.net/9660.html; see also, Yicai.com. 2012. "The Animals Asia Foundation rejects as ridiculous the 'Eight Nation Alliance' charge of the China Traditional Chinese Medicine Association" [in Chinese]. Yicai.com, 15 May. Available at https://www.yicai.com/news/1726833.html; and Zhao Nanyuan. 2011. "The essence of animal rights argument is anti-humanity" [in Chinese]. Available at https://www.douban. com/group/topic/19769734/.

99 Jia Qian et al. 2003. A Study on the Conservation Strategy for the Protection of Endangered Species for Use in Traditional Chinese Medicine. Available at http://blog.sohu.com/s/NTg0MD AyMTQ/233192966.html.

100 State Forestry and Grassland Bureau. "An introduction to the State Forestry and Grassland Bureau" [in Chinese]. Available at http://www.forestry.gov.cn/main/20/20180418/69.html.

${ }^{101}$ State Forestry Bureau. 2009. "The past and future of the budget reform in the forestry bureaus in the last 60 years of the People's Republic of China" [in Chinese]. 30 September. Available at http://www.forestry.gov.cn/main/1017/20090930/266061.html.

102 State Forestry and Grassland Bureau. 2019. 2019 National Government Agency Budget: The State Forestry and Grassland Bureau [in Chinese]. Available at http://www.forestry.gov. cn/main/1017/20090930/266061.html.

103 China Statistical Bureau. 2019. "Statistical summary of the wildlife protection management stations across the country in 2017" [in Chinese]. Chinabaogao.com, 26 August. Available at http://data.chinabaogao.com/nonglinmuyu/2019/0R644391H019. html.

104 Shanshui Nature Protection Center. 2020. "After scrutinizing 1552 wildlife crimes, we found....,". A Shanshui Nature Protection Center study, published on 29 February, at http://kuaibao.qq.com/s/20200229A0AXIG00?refer=spider.

105 Fazhi Ribao (Rule of Law News). 2018. "Jiangxi uncovers a major criminal case involving the trafficking of more than 17,000 provincial protected wild animals" [in Chinese]. Fazhi Ribao, 5 July. Available at http://www.tjxqcaw.gov.cn/tszs/ tjxqcaw-ihexfcvi9714880.shtml.

106 Tan Hong. 2019. "Jiangxi wildlife farming annual revenue reached 10 billion yuan" [in Chinese]. Jiangxi information net, 24 December. Available at https://baijiahao.baidu.com/s?id= $1653795398210394087 \&$ wfr=spider \&for=pc.

107 Wang Tong. 2017. "An investigation of the development of wildlife breeding industry in Hubei" [in Chinese]. Hubei Daily, 9 December. Available at http://news.xnnews.com.cn/snxw/2017 12/t20171209_2891715.shtml.

108 Mu Jingjun. 2014. "Heilongjiang's three-year campaign resulted in doubling forestry industry revenues" [in Chinese]. China Industry Development Research Information network, 18 March. Available at http://www.chinaidr.com/tradenews/201403/18203.html.

109 For details of Zhejiang's wildlife farming in the early 2000s and farm numbers, see Zhu Guishou et al. 2008. "An analysis of the current state of Zhejiang's wildlife farming industry" [in Chinese]. Journal of Zhejiang University of
Agriculture and Forestry 25(1): 109-113; for details of Zhejiang's wildlife farming operation by 2018, see Yang Liu et al. "The current state and development options of Zhjiang's wildlife farming industry". Journal of Zhejiang Forestry Science and Technology 39(2): 98-102.

110 Zhu Kaiming. 2012. "Measures for accelerating the development of Hunan's wildlife farming industry" [in Chinese]. Hunan Forestry Science and Technology 3: at 73, 74, 81.

${ }^{111}$ Zhu Hua. 2013. "Two thirds of the daily consumption of 10 tons of snakes in Changsha are wildlife caught" [in Chinese]. Changsha Evening News, 25 June. Available at https://hn.rednet. $\mathrm{cn} / \mathrm{c} / 2013 / 06 / 25 / 3053031 . \mathrm{htm}$.

112 For his views on the trade ban, see his article "Is the interest of the breeding masses lighter than a feather?" Kuaibao repost, 28 February 2020. Available at https://kuaibao.qq.com/ s/20200228A06OYW00.

113 The data came from the public data platform for searching non-governmental organisations in China. Available at http://www.chinanpo.gov.cn/search/orgcx.html.

114 Ecological Well-being Action Team. 2020. "We ask 'China Association of Wildlife Protection' to make public where it acquired and how it is going to spend 149 million yuan, an appeal from Wang Baoqin, a protester of Heilongjiang's environmental pollution" [in Chinese]. Reposted on Sohu at https://www.sohu.com/a/376952644_749931.

115 CCTV. 2012. "Jiangxi exotic food restaurants as designated official catering venues were involved in massive slaughter of macaques" [in Chinese]. Xinjing News, 28 November. Available at http://www.xinhuanet.com//politics/ 2012-11/28/c_124012509.htm.

116 Guangxiwsh. "An inspection tour of Guangxi: Guangxi officials are investigated for offering pangolin at a catering event" [in Chinese].

117 WeChat interview with a local forestry bureau deputy chief of Jiangxi province, 29 July 2019.

118 Conversation with the head of a local animal protection association, 16 July 2019, Beijing.

119 China.com. 2010. "An overview of the budget of 35 national government agencies: the first year of public disclosure" [in Chinese]. China.com, 12 April. Available at http://www.china. com.cn/economic/txt/2010-04/12/content_19793089.htm.

Note: The annual budgets of China's Defence Ministry, the Foreign Affairs Ministry, the Public Security Ministry and the National Security Ministry were not on the list.

${ }^{120}$ Finance.sina.com.cn. 2012. "Founder of Guizhentang said: Opposition to our company is opposition to the government" [in Chinese]. finance.sin.com.cn, 20 February. Available at http://finance.sina.com.cn/china/20120220/094711411247.shtml.

121 Xangying Shi et al. 2020. "Public perception of wildlife consumption and trade during the COVID-19 outbreak". Biodiversity Science 28(5): 630-643.

122 Ministry of Agriculture and Rural Affairs of China. 2020. "The Ministry of Agriculture releases the Livestock and Poultry Genetic Resource Catalogue". 29 May. Available at http://www. gov.cn/xinwen/2020-05/29/content_5515954.htm. 
Copyright of Environmental Policy \& Law is the property of IOS Press and its content may not be copied or emailed to multiple sites or posted to a listserv without the copyright holder's express written permission. However, users may print, download, or email articles for individual use. 